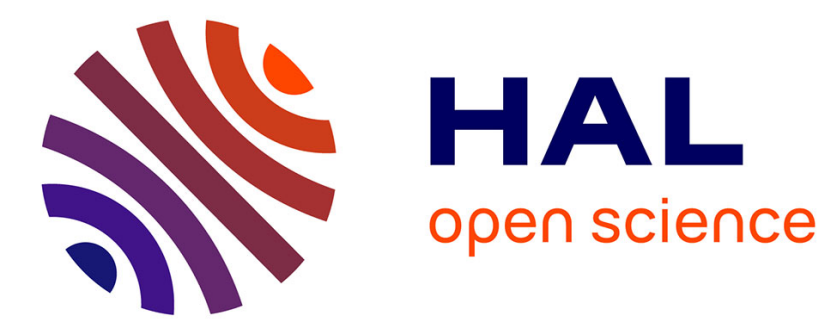

\title{
Oxidation behaviour of simple and Pt-modified aluminide coatings on IN738 at $1100{ }^{\circ} \mathrm{C}$
}

Y. Niu, W. Wu, D. Boone, J. Smith, J. Zhang, C. Zhen

\section{To cite this version:}

Y. Niu, W. Wu, D. Boone, J. Smith, J. Zhang, et al.. Oxidation behaviour of simple and Pt-modified aluminide coatings on IN738 at $1100{ }^{\circ} \mathrm{C}$. Journal de Physique IV Proceedings, 1993, 03 (C9), pp.C9511-C9-519. 10.1051/.jp4:1993954 . jpa-00252394

\section{HAL Id: jpa-00252394 https://hal.science/jpa-00252394}

Submitted on 1 Jan 1993

HAL is a multi-disciplinary open access archive for the deposit and dissemination of scientific research documents, whether they are published or not. The documents may come from teaching and research institutions in France or abroad, or from public or private research centers.
L'archive ouverte pluridisciplinaire HAL, est destinée au dépôt et à la diffusion de documents scientifiques de niveau recherche, publiés ou non, émanant des établissements d'enseignement et de recherche français ou étrangers, des laboratoires publics ou privés. 


\title{
Oxidation behaviour of simple and Pt-modified aluminide coatings on IN738 at $1100^{\circ} \mathrm{C}$
}

\author{
Y. Niu $\left({ }^{1, *}\right)$, W. T. Wu $\left({ }^{1}\right)$, D. H. Boone $\left({ }^{2}\right)$, J. S. Smith $\left({ }^{3}\right)$, J. Q. Zhang $\left({ }^{1}\right)$ \\ and C. L. Zhen $\left.{ }^{1}\right)$
}

( $\left.{ }^{1}\right)$ Corrosion Science Lab., Institute of Corrosion and Protection of Metals, Academia Sinica, Shenyang 110015, China

$\left({ }^{2}\right)$ Boone and Associates, 2412 Cascade Drive, Walnut Creek, California 94598, U.S.A.

$\left({ }^{3}\right)$ Howmet Corporation, Thermatech Coatings Division, 555 Benston Road, Whitehall, Michigan 49461, U.S.A.

\begin{abstract}
The oxidation of both low and high-activity simple and Pt-modified aluminide coatings on nickel base superalloy IN738 has been studied in static air at $1100^{\circ} \mathrm{C}$ up to $1000 \mathrm{~h}$. For all coatings oxidation followed a parabolic law up to $400 \mathrm{~h}$. The two Pt-modified coatings showed better protectiveness with lower mass gains and smaller rate constants, especially for long reaction times. The presence of $\mathrm{Pt}$ significantly improved the resistance to $\gamma^{\prime}-\mathrm{Ni}_{3} \mathrm{Al}$ formation, promoted selective oxidation of aluminium by preventing the transport of other elements outwards to $\mathrm{Al}_{2} \mathrm{O}_{3}$ scale and resulted in the formation of purer, slower-growing and more adherent $\mathrm{Al}_{2} \mathrm{O}_{3}$ scales, delaying the onset of scale spalling for two types of coatings and of oxide nodules growth for the high aluminium activity coating.
\end{abstract}

\section{Introduction.}

Pt-modified aluminide coatings have significantly superior resistance to cyclic oxidation and hot-corrosion over the simple aluminide coatings without degrading the mechanical properties of substrates [1-5]. The beneficial effects of $\mathrm{Pt}$ on the coating performance are believed to result mainly from an improved protectiveness of alumina scales by a number of possible mechanisms [5-9]. However, insufficient information has been available on the isothermal oxidation of these materials, while the mechanisms of Pt effects have not yet been completely clarified. This paper examines the isothermal oxidation kinetics of two simple and Pt-modified aluminides and their degradation processes with the corresponding changes in morphology, microstructure and composition of the scales.

\section{Experimental.}

Two structural types of simple and Pt-modified aluminide coatings were prepared on IN738 by aluminizing either directly the substrate or the substrate with a prediffused electroplated platinum layer by high-temperature low-activity (HTLA) CVD process (outward-type, LA

$\left(^{\star}\right)$ Present address: Instituto di Chimica, Facoltà di Ingegneria, Universita di Genova, Fiera del Mare, Pad. D, 16129 Genova, Italy 
coating and LA + Pt coating) or in low-temperature high-activity (LTHA) CVD process (inward-type, HA coating and HA + Pt coating). The Pt-modified coatings ( $\mathrm{LA}+\mathrm{Pt}$ and $\mathrm{HA}+\mathrm{Pt}$ coating) consisted of $\mathrm{PtAl}_{2}$ and Al-rich $\beta$-NiAl phase and had an average thickness of $56 \mu \mathrm{m}$ with a diffusion zone of $23 \mu \mathrm{m}$, while the corresponding Pt-free coatings (LA and HA coating) were single-phase $\beta$-NiAl of $58 \mu \mathrm{m}$ thick with a diffusion zone of $27 \mu \mathrm{m}$. The details of coatings processing and morphologies have been reported elsewhere [10]. The samples $(25 \times 13 \times 3 \mathrm{~mm})$ were oxidized at $1100^{\circ} \mathrm{C}$ in air up to $1000 \mathrm{~h}$. Short-time tests (before $100 \mathrm{~h}$ ) were carried out with a thermobalance, while for longer-time tests (up to $1000 \mathrm{~h}$ ) a horizontal furnace was used. The oxidized samples were examined by optical metallography, scanning electron microscope (SEM), X-ray diffraction (XRD) and electron probe microanalysis (EMPA) for morphological observation and phase identification.

\section{Results.}

3.1 KinETics. - The oxidation kinetic curves of the four coatings are shown in figure 1 with the parabolic rate constants calculated from data up to $400 \mathrm{~h}$. In comparison to LA and $\mathrm{HA}$ coating, $\mathrm{LA}+\mathrm{Pt}$ and $\mathrm{HA}+\mathrm{Pt}$ coating showed lower mass gains, smaller reaction rates and more protective behaviour up to $1000 \mathrm{~h}$ oxidation. However, also LA and HA coatings showed only small mass gains up to $1000 \mathrm{~h}$ and did not undergo catastrophic oxidation. Also, no important difference in kinetics behavior between the low and high-activity coatings, even in the presence of platinum, was observed.

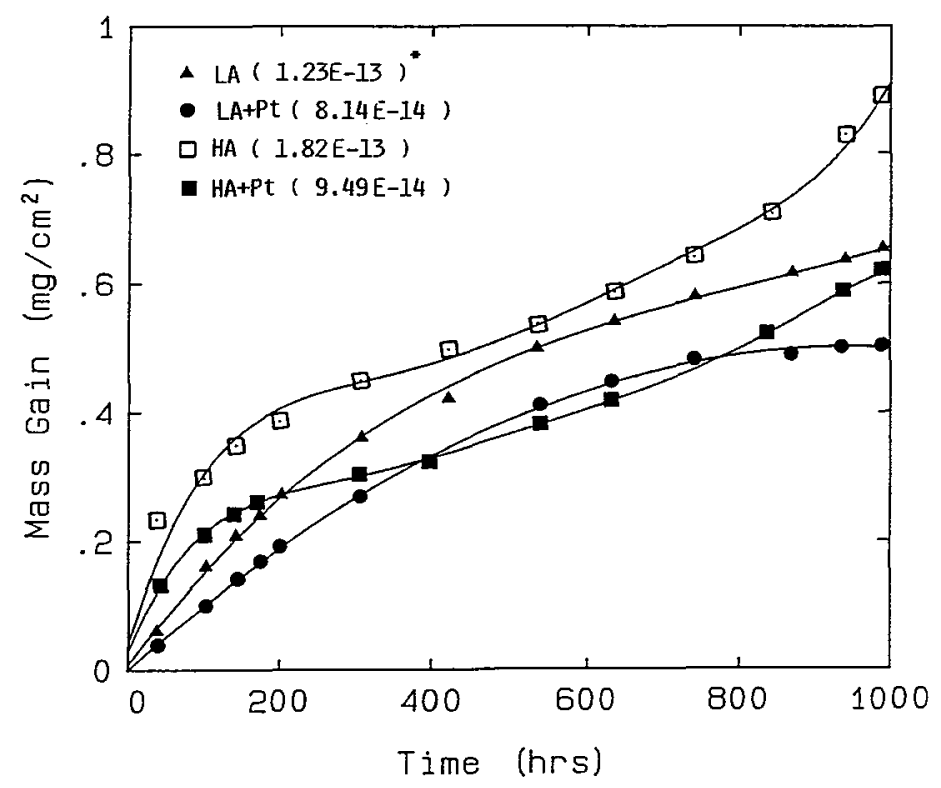

Fig. 1. - Isothermal oxidation kinetics of two simple (LA and HA coatings) and Pt-modified aluminide coatings (LA + Pt and HA + Pt coatings) in air at $1100^{\circ} \mathrm{C}$ for times up to $1000 \mathrm{~h}\left(\left(^{*}\right)\right.$ Parabolic constants $\left.K_{\mathrm{p}}\left(\mathrm{g}^{2} \mathrm{~cm}^{-4} \mathrm{~s}^{-1}\right)\right)$. 
3.2 IDENTIFICATION OF PHASES ON TOP SURFACES OF COATINGS. - The identification of the phases of the surface of the coatings oxidized has been carried out by X-ray diffraction directly on the corroded sample surfaces. Table I summarizes the phases observed for the four coatings as functions of oxidation time. $\gamma^{\prime}-\mathrm{Ni}_{3} \mathrm{Al}$ was detected after $274 \mathrm{~h}$ for LA coating and $120 \mathrm{~h}$ for HA coating, while the XRD peaks of $\beta$-NiAl disappeared after $515 \mathrm{~h}$ for LA coating and $624 \mathrm{~h}$ for $\mathrm{HA}$ coating, respectively, as a consequence of degradation into $\gamma^{\prime}-\mathrm{Ni}_{3} \mathrm{Al}$ of most $\beta-\mathrm{NiAl}$ close to the $\alpha-\mathrm{Al}_{2} \mathrm{O}_{3}$ scale. For the $\mathrm{Pt}-\mathrm{Al}$ coatings $\mathrm{PtAl}_{2}$ phase was covered by a continuous layer of $\alpha-\mathrm{Al}_{2} \mathrm{O}_{3}$ already after short times (around $30 \mathrm{~h}$ ), the appearance of $\gamma^{\prime}-\mathrm{Ni}_{3} \mathrm{Al}$ for the Pt-modified coatings was postponed up to $400 \mathrm{~h}$ for $\mathrm{LA}+\mathrm{Pt}$ coating and $700 \mathrm{~h}$ for $\mathrm{HA}+\mathrm{Pt}$ coating: however, $\beta$-Ni(Pt)Al could still be observed even up to $850 \mathrm{~h}$ for both coatings. After longer times $(950 \mathrm{~h})$, the surface region of the four coatings was mainly composed of $\alpha-\mathrm{Al}_{2} \mathrm{O}_{3}$ and $\gamma^{\prime}-\mathrm{Ni}_{3} \mathrm{Al}$, whereas on $\mathrm{HA}$ and $\mathrm{HA}+\mathrm{Pt}$ coatings weak peaks corresponding to $\mathrm{Cr}_{2} \mathrm{O}_{3}$ and to the $(\mathrm{Ni}, \mathrm{Co}) \mathrm{Cr}_{2} \mathrm{O}_{4}$ spinel were also observed. Thus, the presence of $\mathrm{Pt}$ in the aluminide coatings significantly improved the oxidation resistance of the coatings and also suppressed the transformation of $\beta$-NiAl into $\gamma^{\prime}-\mathrm{Ni}_{3} \mathrm{Al}$.

Table I. - Structure of the coatings oxidized in air at $1100^{\circ} \mathrm{C}$ for times up to $1000 \mathrm{~h}$.

\begin{tabular}{|c|c|c|c|c|}
\hline & \multicolumn{2}{|c|}{ CVD Low Al Activity Coatings } & \multicolumn{2}{c|}{ CVD High Al Activity Coatings } \\
\hline Time, h & LA & LA+Pt & HA & HA+Pt \\
\hline 0 & $\beta$ & $\beta, \mathrm{PtAl} 2$ & $\beta$ & $\beta, \mathrm{PtAl}_{2}$ \\
\hline 30 & $\alpha, \beta$ & $\alpha, \beta$ & $\alpha, \beta$ & $\alpha, \beta$ \\
\hline 130 & $\alpha, \beta$ & $\alpha, \beta$ & $\alpha, \beta, \gamma^{\prime}$ & $\alpha, \beta$ \\
\hline 274 & $\alpha, \beta, \gamma^{\prime}$ & $\alpha, \beta$ & $\alpha, \beta, \gamma^{\prime}$ & $\alpha, \beta$ \\
\hline 400 & $\alpha, \beta, \gamma^{\prime}$ & $\alpha, \beta, \gamma^{\prime}$ & $\alpha, \beta, \gamma^{\prime}$ & $\alpha, \beta$ \\
\hline 515 & $\alpha, \gamma^{\prime}$ & $\alpha, \beta, \gamma^{\prime}$ & $\alpha, \beta, \gamma^{\prime}$ & $\alpha, \beta$ \\
\hline 650 & $\alpha, \gamma^{\prime}$ & $\alpha, \beta, \gamma^{\prime}$ & $\alpha, \gamma^{\prime}$ & $\alpha, \beta$ \\
\hline 700 & $\alpha, \gamma^{\prime}$ & $\alpha, \beta, \gamma^{\prime}$ & $\alpha, \gamma^{\prime}$ & $\alpha, \beta, \gamma^{\prime}$ \\
\hline 850 & $\alpha, \gamma^{\prime}$ & $\alpha, \beta, \gamma^{\prime}$ & $\alpha, \gamma^{\prime}$ & $\alpha, \beta, \gamma^{\prime}$ \\
\hline 950 & $\alpha, \gamma^{\prime}$ & $\alpha, \gamma^{\prime}$ & $\alpha, \gamma^{\prime}$ & $\alpha, \gamma^{\prime}$ \\
\hline 1000 & $\alpha, \gamma^{\prime}$ & $\alpha, \gamma^{\prime}$ & $\left.\alpha, \gamma^{\prime}, \mathrm{Cr}_{2} \mathrm{O}_{3}{ }^{*}\right)$ & $\alpha, \gamma^{\prime}, \mathrm{Cr}_{2} \mathrm{O}_{3}\left(^{*}\right)$ \\
& & $(\mathrm{Ni}, \mathrm{Co}) \mathrm{Cr}_{2} \mathrm{O}_{4}$ & $\left(\mathrm{Ni}, \mathrm{Co}_{2}\right) \mathrm{Cr}_{2} \mathrm{O}_{4}$ \\
\hline
\end{tabular}

$\alpha=\alpha-\mathrm{Al}_{2} \mathrm{O}_{3} ; \quad \beta=\beta-\mathrm{NiAl} ; \quad \gamma^{\prime}=\gamma^{\prime}-\mathrm{Ni3Al} ; \quad(*)$ possible phase

3.3 SURFACE MORPHOLOGY ON LOW Al ACTIVITY (LA AND LA + Pt) COATINGS. - During the early oxidation stage (up to $130 \mathrm{~h}$ for LA coating and $515 \mathrm{~h}$ for $\mathrm{LA}+\mathrm{Pt}$ coating) the two coatings developed continuous and uniform $\mathrm{Al}_{2} \mathrm{O}_{3}$ scales without spallation and significant change of surface scale morphology. The content of Al in outer surface zone increased significantly with time, while the contents of Ni, $\mathrm{Cr}$ and Pt (for LA + Pt coating) decreased. Figure 2 shows cross-section micrographs of both coatings after $74 \mathrm{~h}$ oxidation with the corresponding EPMA results. The $\mathrm{Al}_{2} \mathrm{O}_{3}$ scales formed on $\mathrm{LA}+\mathrm{Pt}$ coating has higher purity $(98$ at $\% \mathrm{Al})$ and 
were thinner and more uniform than those grown on LA coating, which contained only 83 at\% $\mathrm{Al}$ and higher substrate elements, especially $\mathrm{Ti}$. Moreover, the $\mathrm{Ni}_{3} \mathrm{Al}$ grains in LA coating were more developed, some of them extending across the whole NiAl layer of the coating.
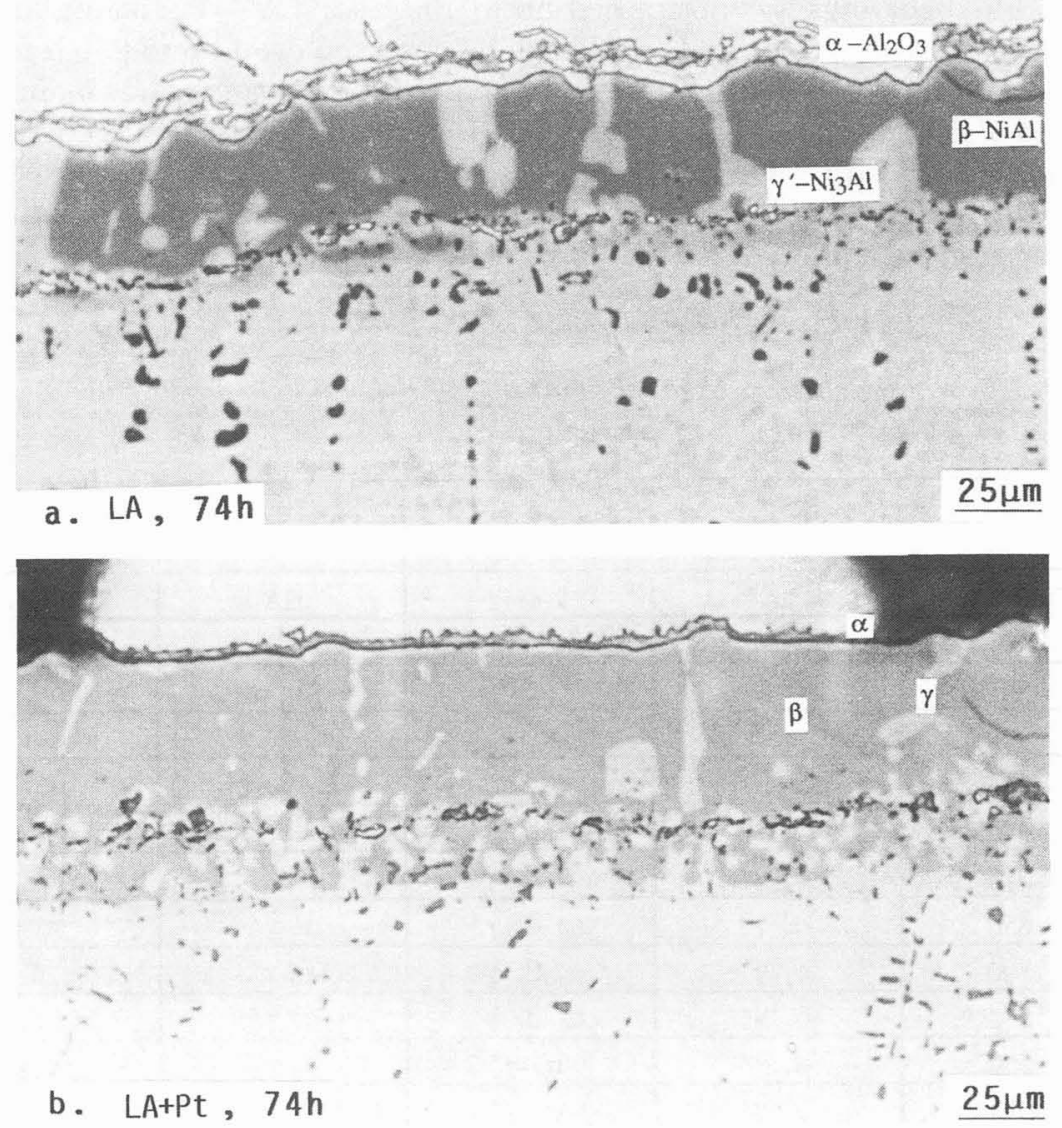

Compositions (at.\%) of oxide scales

$\begin{array}{lccccc} & \text { Al } & \text { Ni } & \text { Cr } & \text { Ti } & \text { Pt } \\ \text { a. LA, 74h } & 82.7 & 5.6 & 1.2 & 10.5 & - \\ \text { b. LAtPt, 74h } & 97.6 & 1.5 & 0.3 & 0.6 & 5.4\end{array}$

Fig. 2. - Cross-sections of LA (a) and LA + Pt (b) coatings after 74 h oxidation in air at $1100^{\circ} \mathrm{C}$. 
The topologies of the original LA and LA + Pt coatings (Figs. 3a, 3a') show polygonal grains surrounded by continuous networks of beta phase boundaries, with larger grains on LA $+\mathrm{Pt}$ coating than on LA coating. However, scale spalling on LA coating occurred after $140 \mathrm{~h}$, developing preferentially along the boundaries (Fig. 3b) and expanding quickly with time. After $400 \mathrm{~h}$ the spalled regions formed a continuous network covering nearly all the sample surface (Fig. 3c) and later propagated towards the grains interior. Actually, a faster-growing mixture of oxides rich in $\mathrm{Ni}$ and $\mathrm{Cr}$ with some $\mathrm{Al}$, Co and $\mathrm{Ti}$ developed later on the areas where repeated spallation occurred, as shown in figures $3 \mathrm{~d}$ and $3 \mathrm{e}$.

Scale spalling on LA + Pt coating was postponed up to $515 \mathrm{~h}$ and occurred only on the boundaries (Fig. 3b'), expanding more slowly with time. After 787 and $850 \mathrm{~h}$ a number of deep holes with trumpet-like morphology were observed on the spalled surface regions (Fig. 3c') but disappeared later, probably being covered by new-developed oxides. After $950 \mathrm{~h}$ the spalled boundaries became more numerous but still discontinuous (Fig. $3 \mathrm{~d}$ '). The unspalled light scale was still pure alumina, while the dark scale on spalled regions was enriched in $\mathrm{Ni}, \mathrm{Al}, \mathrm{Cr}$ and $\mathrm{Pt}$ with little Co and $\mathrm{Ti}$ (Fig. 3e'). A reasonably high Pt concentration was found in all the spalled regions, suggesting that $\mathrm{Pt}$ accumulated at the $\mathrm{Al}_{2} \mathrm{O}_{3}$-coating interface during oxidation.

3.4 SURFACE MORPHOLOGY ON HIGH Al ACTIVITY (HA AND HA + Pt) COATINGS. - Evident scale spallation was observed on HA coating after $510 \mathrm{~h}$, while many, partially continuous dark grooves formed on the whole surface as time increased up to $620 \mathrm{~h}$ (Fig. 4a). At variance with LA coating, a number of oxide nodules developed after $944 \mathrm{~h}$ (Fig. $4 \mathrm{~b}$ ) and their number and size increased with time up to $1000 \mathrm{~h}$ (Fig. 4c). They had nonuniform composition, containing prevailingly either $\mathrm{Cr}$ or $\mathrm{Ni}$ or $\mathrm{Ti}$, while beneath the spalled nodules a mixture of substrate elements oxides was observed. A cross-section of the same sample, figure $4 \mathrm{~d}$, shows that at some places the coating was completely destroyed due to development of nonprotective oxides along $\mathrm{Ni}_{3} \mathrm{Al}$ paths across the whole layer. This degradation morphology is probably related to the formation of surface oxide nodules as shown in figures $4 \mathrm{~b}$ and $4 \mathrm{c}$. Spalling of the oxide scales of $\mathrm{HA}+\mathrm{Pt}$ coating occurred later than for the HA coating (after $700 \mathrm{~h}$ ). As for the LA + Pt coating, a number of holes some of which were covered by oxides grown after spalling, appeared in a limited time range (from 820 to $944 \mathrm{~h}$ ), figures $4 \mathrm{a}^{\prime}$ and $4 \mathrm{~b}$ '. Up to $1000 \mathrm{~h}$ the whole scales became flatter without deep depressions and grooves (Fig. 4c'), part of which consisted of $\mathrm{Al}_{2} \mathrm{O}_{3}$ and the rest of a mixture of oxides rich in $\mathrm{Al}$ and $\mathrm{Ni}$ with some $\mathrm{Ti}$, $\mathrm{Cr}$ and Co. However, no platinum was observed on the surface, probably because the spalled regions where Pt enriched had already been covered by rapidly-growing mixtures of oxides formed following spallation.

\section{Discussion.}

4.1 GenERAL OXIDATION BEHAVIOR. - The isothermal oxidation of the present coatings involves the following steps: initial development of continuous $\mathrm{Al}_{2} \mathrm{O}_{3}$ scales, formation of $\mathrm{Ni}_{3} \mathrm{Al}$ beneath $\mathrm{Al}_{2} \mathrm{O}_{3}$ and its propagation inwards and eventual scale spallation with subsequent formation of poorly-protective oxides containing $\mathrm{Ni}, \mathrm{Cr}, \mathrm{Ti}$ and $\mathrm{Co}$. The last step results in rapid scale growth and increases the tendency to spall. Although the same sequence of events occurs for all coatings, those with Pt exhibit better general oxidation behavior. In particular, numerous oxide nodules appear on HA coating after spalling on the initially formed oxide scale, which in turn spalls easily producing further catastrophic oxidation. 


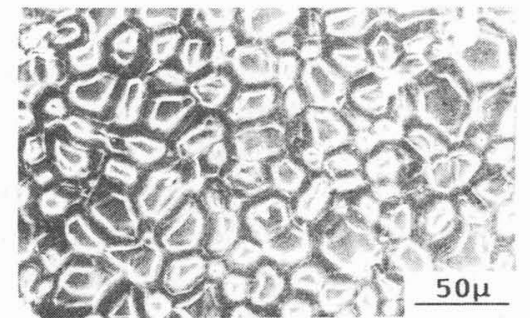

a. LA, as-coated

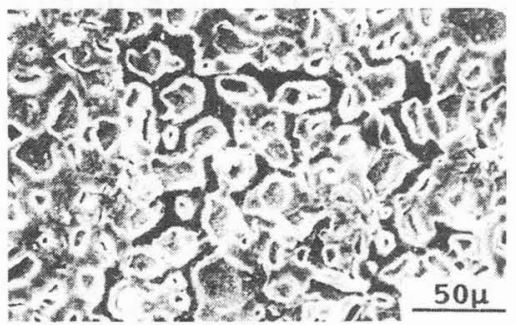

b. $L A, 140 \mathrm{~h}$

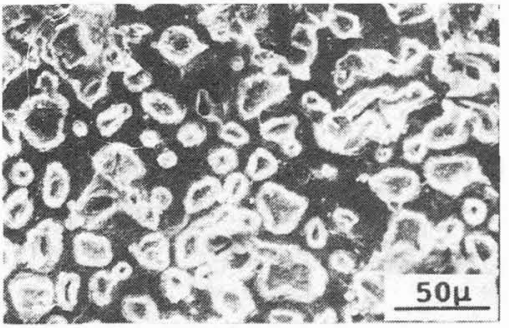

c. LA, 400h

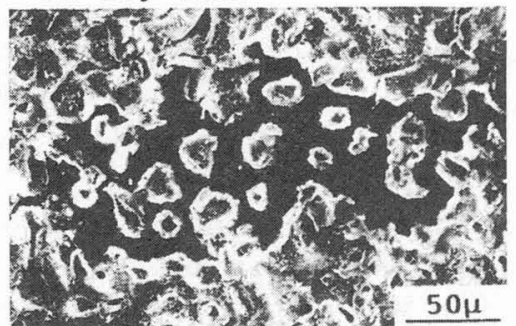

d. $\mathrm{LA}, 787 \mathrm{~h}$

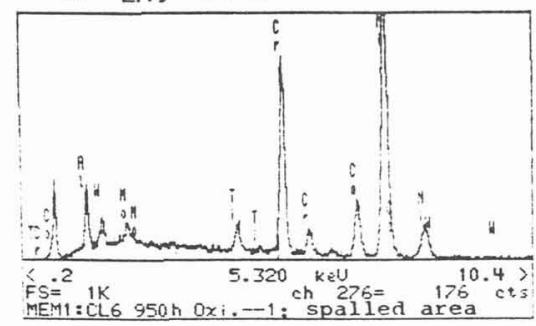

e. LA, 950h spalled zone

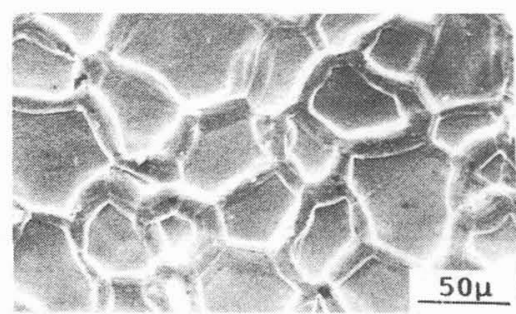

$a^{\prime}$. LA+Pt, as-coated

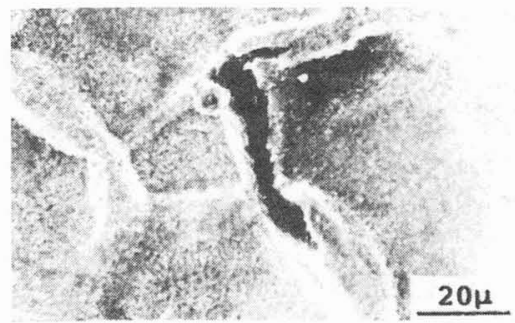

$b^{\prime}$. LA+Pt, 515h

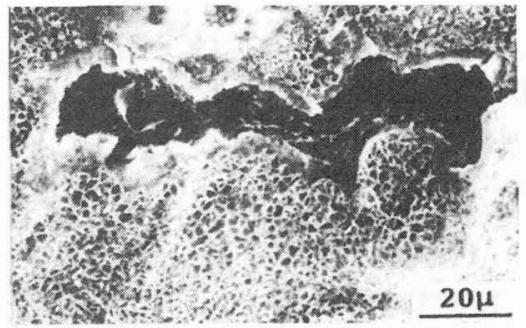

$$
c^{\circ} \text {. LA+Pt, } 787 \mathrm{~h}
$$

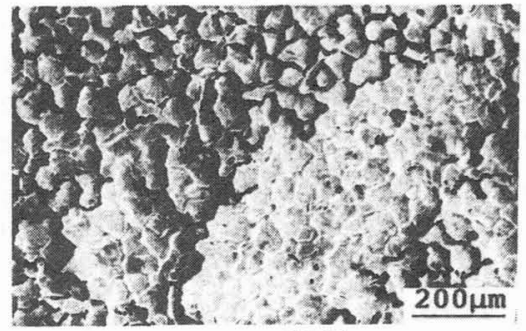

d'. LA+Pt, 950h

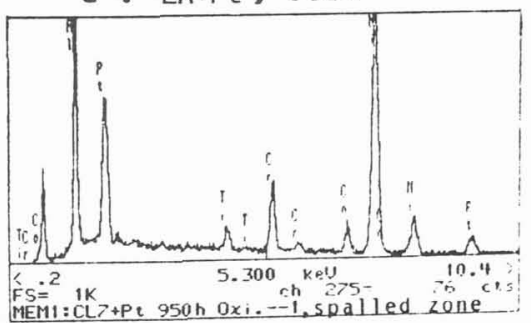

$e^{\prime}$ spalled zone of $d^{\prime}$

Fig. 3. - SEM morphologies and compositions of the scales formed on LA and LA + Pt coatings oxidized in air at $1100^{\circ} \mathrm{C}$ for the different times up to $950 \mathrm{~h}$. 

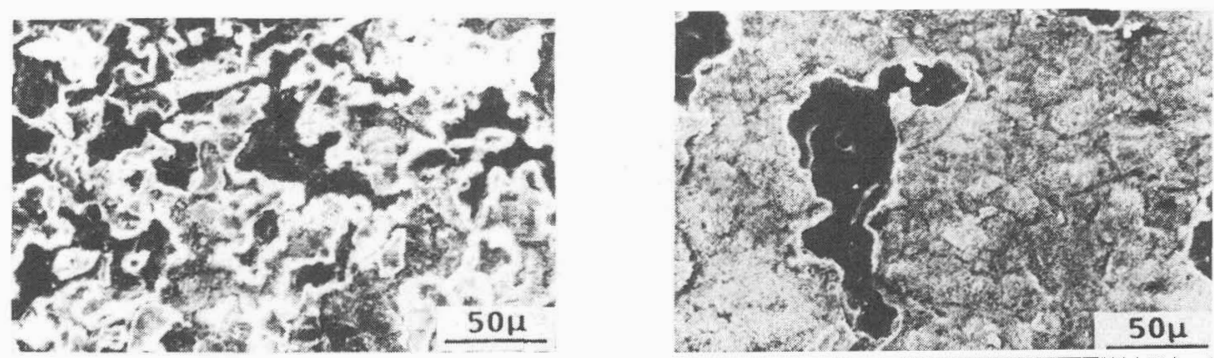

a. $\mathrm{HA}, 630 \mathrm{~h}$

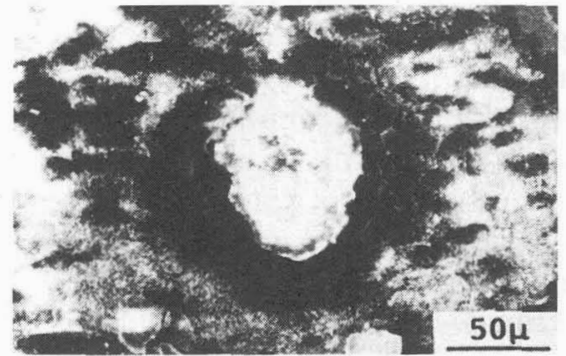

$$
\text { a'. } H A+P t, 820 h
$$

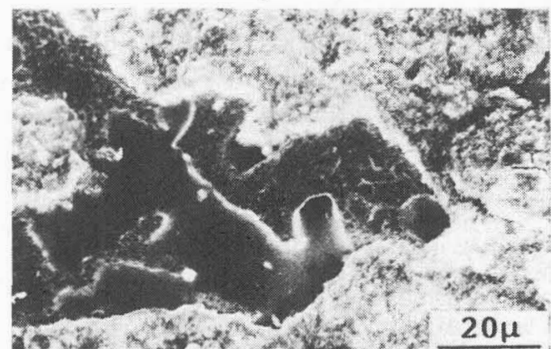

\section{b. $H A, 944 h$}

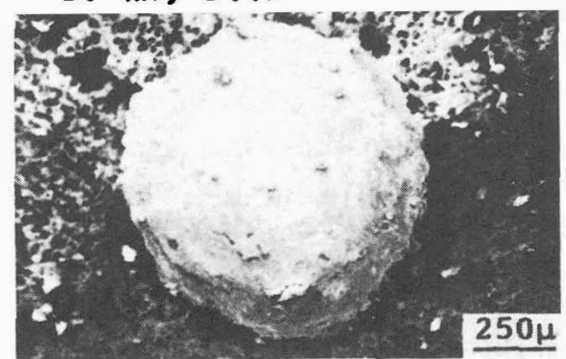

c. HA, 1000h

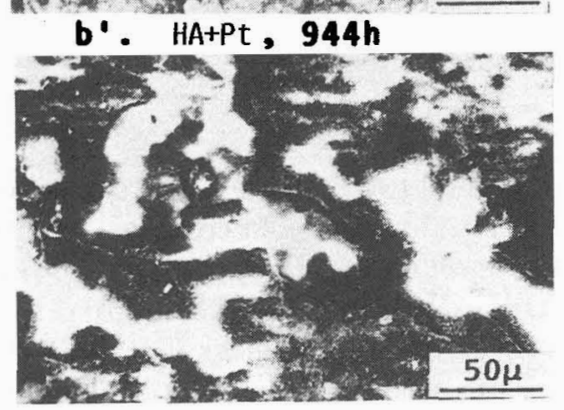

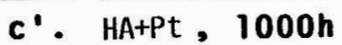

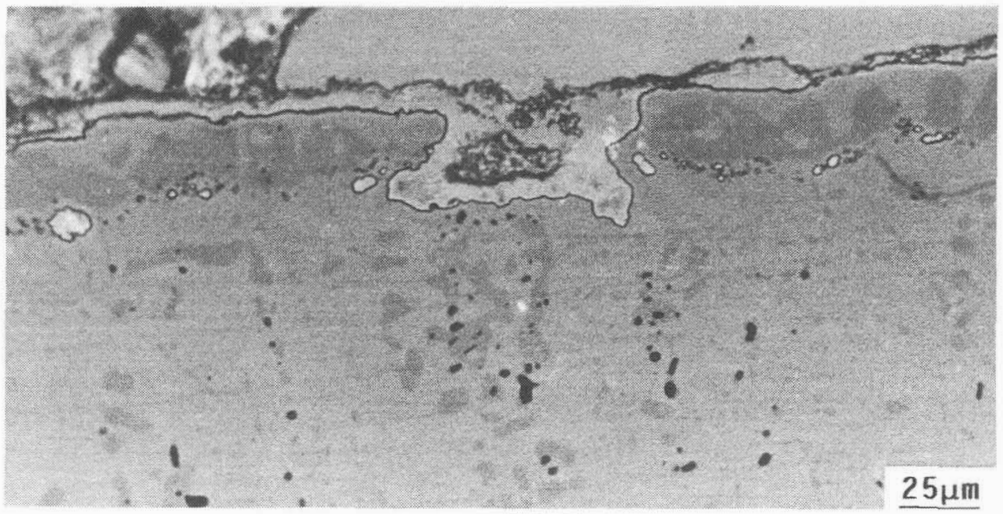

d. $H A$, cross section after l000h oxidation

Fig. 4. - Morphologies of scales on HA and $\mathrm{HA}+\mathrm{Pt}$ coatings oxidized in air at $1100^{\circ} \mathrm{C}$ up to $1000 \mathrm{~h}$. 
4.2 THE ROLE OF PLATINUM. - The incorporation of $\mathrm{Pt}$ in two types of aluminide coatings has a number of beneficial effects on their isothermal oxidation resistance. First, the purity of the initially formed $\mathrm{Al}_{2} \mathrm{O}_{3}$ scale is much higher on the Pt-modified coatings, producing slower scale growth rates and indicating a more effective selective oxidation of aluminium. Moreover, due to the superior protectiveness of the oxide scale, the rate of the NiAl degradation into $\mathrm{Ni}_{3} \mathrm{Al}$ beneath the oxide scale is significantly lowered in the Pt-modified coatings. Finally, Pt significantly delays the onset of scale spallation, while the formation of oxide nodules observed on the high-activity aluminide coatings is suppressed.

The improved oxidation resistance of $\mathrm{Pt}-\mathrm{Al}$ coatings may be due to many reasons. In fact, $\mathrm{Pt}$ produces at the same time an increase of the diffusivity of $\mathrm{Al}$ and a decrease of that of other alloy components [5, 9], so that the Pt-containing layer acts as a filter enabling $\mathrm{Al}$ to diffuse more easily than the other elements, resulting in the formation of higher purity alumina scales. This also helps to form a continuous $\mathrm{Al}_{2} \mathrm{O}_{3}$ layer more rapidly and under lower $\mathrm{Al}$ concentrations as well as to maintain the $\mathrm{NiAl}$ phase at the coating surface for longer periods. The improved scale adherence is a result of the combination of various factors, including higher oxide purity [5], strengthening of the coating-oxide bonding [11], enhanced nucleation of alumina [11], reduced stress accumulation in the scale due to slower growth rates and inhibition of inward oxygen diffusion $[12,13]$ and finally improved mechanisms for stress relief in the scales $[7,12]$ due to an increased scale plasticity [11]. Also, the mechanism of matter transport through the scale may be changed, as suggested for the reactive elements effect [ 11 , 12].

4.3 SCALE SPALling AND COATING DEGRADATION. - Scale spalling starts along the boundaries of the LA and LA + Pt coatings, where the scales are thicker and contain larger amounts of substrate elements, in agreement with the presence of less $\mathrm{Pt}$ and lower $\mathrm{Al}_{2} \mathrm{O}_{3}$ purity in these regions before oxidation. Therefore, the oxide scales formed on the boundary regions may allow faster matter transport in both phases. In particular, scale spalling as well as nodules formation are generally associated with the formation of some $\mathrm{Ni}_{3} \mathrm{Al}$. Moreover, the difference in thickness and composition between boundaries and flat scale regions may induce higher stress concentrations and yield earlier spalling at these points, especially as a result of mismatch of thermal stresses during cooling.

Coating degradation during oxidation is due to the combination of development of $\mathrm{Ni}_{3} \mathrm{Al}$ and of mixed oxides within the coating. In particular, $\mathrm{Ni}_{3} \mathrm{Al}$ develops both at the coating-scale interface, as a result of Al depletion due to oxidation, and at the coating-substrate interface, due to Al diffusion into the substrate. Thus, the $\mathrm{Ni}_{3} \mathrm{Al}$ islands grow in opposite directions and can eventually connect forming paths crossing the whole coating thickness. Due to their lower oxidation resistance, these $\mathrm{Al}$-depleted paths transform later into oxide stringers containing substrate elements in the Pt-free coatings, leading eventually to their failure.

\section{Conclusions.}

1) The oxidation kinetics of the four coatings followed a parabolic rate law up to about $400 \mathrm{~h}$, but Pt-modified coatings showed smaller oxidation rates than simple coatings.

2) The coatings oxidation generally involved the development of continuous $\mathrm{Al}_{2} \mathrm{O}_{3}$ scales with formation of $\mathrm{Ni}_{3} \mathrm{Al}$ at the scale/coating interface and its propagation across the whole NiAl layer. Moreover, scale spalling led to fast growth of poorly-protective oxides across the whole coatings, resulting eventually in their complete degradation. 
3) The presence of Pt had significant beneficial effects on the oxidation resistance of both coatings by promoting the formation of purer and thinner $\mathrm{Al}_{2} \mathrm{O}_{3}$ scales during the early stages, lowering the rate of NiAl degradation and delaying the onset of scale spalling.

4) The high activity aluminide coating (HA coating) oxidized faster than low activity aluminide coating ( $\mathrm{LA}$ coating), especially for long times, while no significant difference in oxidation behavior between the two Pt-modified coatings ( $\mathrm{LA}+\mathrm{Pt}$ and $\mathrm{HA}+\mathrm{Pt}$ ) was observed.

\section{Acknowledgements.}

The authors would like to express their thanks to Profs. F. Gesmundo and F. Viani of Genova University (Italy) for their support and help in the discussion, and to Mrs. Yuqing Deng for her help in metallography.

\section{References}

[1] BoOne D.H., STREiff R., J. Vac. Sci. Technol. A3 (1985) 2578.

[2] Boone D.H., Deb P., Purivs L.I., Rigney D.V.,J. Vac. Sci. Technol. A3 (1985) 2557.

[3] Deb P., Boone D.H., Manley T.F., J. Vac. Sci Technol. A5 (1987) 3366.

[4] Wu W., RahMel A., Schorr M., Oxid. Met. 22 (1984) 59.

[5] SChAEFfER J., KIM G.M., MEIER G.H., PETtiT F.S., The Role of Active Elements in the Oxidation Behavior of High Temperature Metals and Alloys, E. Lang Ed. (Elsevier London, 1989) p. 231.

[6] Felten E.J., Pettit F.S., Oxid. Met. 10 (1976) 189.

[7] Fountain J.G., Golightly F.A., Stott F.H., Wood G.C., Oxid. Met. 10 (1976) 789.

[8] Allam 1.M., Akuezue H.C., Whittle D.P., Oxid. Met. 14 (1980) 517.

[9] Tatlock G.J., Hurd T.J., PunNi J.S., Platinum Met. Rev. 31 (1987) 26.

[10] MCCLOSKey M.A., "Plastic Instability of Pt-Modified and Unmodified Aluminide Coatings During $1100^{\circ} \mathrm{C}$ ", United States Navy, B.S. Thesis (1986).

[11] HunTZ A.M., The Role of Active Elements in the Oxidation Behavior of High Temperature Metals and Alloys, E. Lang Ed. (Elsevier London, 1989) p. 81.

[12] JEDLINSKI J., The Role of Active Elements in the Oxidation Behavior of High Temperature Metals and Alloys E. Lang Ed. (Elsevier London, 1989) p. 131.

[13] Tatlock G.J., Hurd T.J., Oxid. Met. 22 (1984) 201. 